\title{
THE COMPOSITION OF PARTIAL MELTS IN A VOLATILE BEARING, REDUCED MANTLE.
}

Odling $^{(1)}$, N.W.A.; Green ${ }^{(2)}$, D.H. and Harte ${ }^{(1)}, B$.

(1) Dept. of Geology and Geophysics, University of Edinburgh, West Mains Rd., Edinburgh, Scotland EH9 3JW, U.K.;

(2) Dept. of Geology, University of Tasmania, G.P.O. Box 252C Hobart, Tasmania, Australia.

The migration and reaction of partial melts (PM) and/or volatile dominated fluids have been commonly invoked to explain chemical enrichments apparent in many upper mantle xenoliths, and such processes are inferred to be important in generating different melt compositions and types of magmatism. In considering these processes it is crucial to understand the relationship between the intensive variables pressure(P), temperature(T) and $\mathrm{fO}_{2}$, and the character of the melts/fluids produced. The determination of the chemical character of PM by direct melting of peridotite in experiments is difficult because crystal growth during quenching severely modifies the composition of the interstitial melt. Thus, despite their perceived importance very little is known about the composition of $\mathrm{PM}$ as a function of $\mathrm{P}, \mathrm{T}, \mathrm{fO}_{2}$ and percentage volatile present.

\section{Determination of partial melt compositions}

In partial melting experiments crystal growth during quenching renders the resultant glasses unrepresentative of partial melts present at high pressure and temperature (Green, 1976). In an attempt to circumvent this problem, and so achieve representative partial melt compositions, stolper(1980)

devised the 'sandwich technique' in which a layer of basalt is placed next to the peridotite to increase the modal proportion of partial melt (basalt) within the charge. During quenching the melt composition is modified only adjacent to crystals and so large areas of glass separated from crystal rich areas will preserve the equilibrium melt composition. This approach, however, suffers from two limitations:

(1) the peridotite and the melt composition used in the basalt layer must be genetically related;

(2) a particular basalt composition can only be used over a restricted temperature range before crystallization results in amounts of melt too small to preserve the equlibrium melt composition.

Where such compositional pairs are available this technique has been employed to examine the position of 'dry' cotectics in $\mathrm{P} / \mathrm{T} / \mathrm{compositional} \mathrm{space} \mathrm{(e.g.} \mathrm{Falloon} \mathrm{et} \mathrm{al.,1988).} \mathrm{In}$ contrast, the compositions of melts generated by the melting of 'wet' peridotite (either fluid saturated or fluid undersaturated) are poorly constrained. The use of the sandwich technique to determine the character of partial melts of 'wet' peridotite requires knowledge of not only the oxide composition of a suitable partial melt but also both the nature and amount of volatile species held in solution. As these are poorly constrained the sandwich technique presents significant problems in its application to the study of partial melting of peridotite in the presence of volatiles.

\section{Determination of EPM by Melt inclusion Synthesis: A New Technique.}

In order to examine the compositions of equilibrium partial melts (EPM) of volatile bearing peridotite we have devised a technique in which EPM are isolated from the bulk of the charge as inclusions in olivine. Olivine plugs were cut from 
San Carlos olivine $\left(\mathrm{F}_{90}\right)$, fractured by thermal stressing and placed adjacent to peridotite mix within a carbon capsule. This was then sealed in an outer Pt capsule along with a buffer assemblage of $\mathrm{WC}_{1} \mathrm{WO}_{2}, \mathrm{WS}_{2}$ and $\mathrm{C}$ and a stearate fluid source. This arangement maintaines the $\mathrm{fO}_{2}$ at approximately one log unit above the buffer reaction iron-wustite and the $\mathrm{fS}_{2}$ one log unit above the reaction of iron to troilite. The volatile fraction of the fluid consists of a $\mathrm{H}_{2} \mathrm{O}-\mathrm{CH}_{4}$ mixture and under fluid saturated conditions is maintained at a constant species ratio by the buffer assemblage. Any melt and/or fluid generated migrates into the fractures in the olivine plug where become entrapped as inclusions up to $100 \mu \mathrm{m}$ in diameter generally of negative euhedral form.

\section{Run conditions and Results.}

Experiments were performed in a piston-cylinder aparatus at $20 \mathrm{kbar} / 1175^{\circ} \mathrm{C}$. The charges consisted of Hawaiian pyrolite 'fertile' peridotite minus $40 \%$ olivine component $(\mathrm{Fe} /(\mathrm{Fe}+\mathrm{Mg})=0.87)$ combined with bulk volatile contents of 1,5 and 20 wt. $\frac{\circ}{8}$ (runs ED63, ED58 and ED65 respectively). In each case the experiments resulted in charges consisting of melt plus crystals all including olivine as an equilibrium phase. The host olivine plug showed in each case a single population of inclusions containing melt only. Analysis of the inclusion glasses (open symbols offigure 1.) shows that they have been modified to varying extents by inward growth of the walls of the inclusion. Assuming that the the Fe/Mg partitioning relationship between volatile bearing melt and olivine is the same as that between dry melt and olivine (Roeder and Emslie, 1970) it is possible to restore the inclusion melt compositions by the addition of olivine until equilibrium with the primary olivine of the charge is reached. The calculated compositions are given in Table 1 . and are plotted in figure 1. (closed symbols). Given here are the results of three experiments in which the melts co-exist with a residual mineralogies of amphibole lherzolite (ED63, estimated 5\% melt), lherzolite (ED58, estimated $20 \%$ melt) and harzburgite (ED65, estimated $40 \%$ melt). The melt compositions calculated vary with percentage fluid added to the charge as follows: 1\% fluid - nepheline normative picrite $(\mathrm{Fe} /(\mathrm{Fe}+\mathrm{Mg})=0.74)$; 5 응 fluid - mildly hypersthene normative $(\mathrm{Fe} /(\mathrm{Fe}+\mathrm{Mg})=0.75)$; 20 of fluid - mildly quartz normative ( $\mathrm{Fe} /(\mathrm{Fe}+\mathrm{Mg})=0.76)$. The variety in melt composition is clearly the result of the migration of the cotectic positions as the phase field of olivine expands with increasing volatile content. Both the nepheline and hypersthene normative melt compositions lie between the 20 and 25 kbar cotectics and their extensions defined for 'dry' hawaiian pyrolite by Falloon et al.(1988) (Figure 1.). The small implied shift of the cotectic positions for these fluid contents towards higher normative olivine contents is probably due to pressure uncertainties as Taylor and Green(1987) have detailed a depolymerizing effect for $\mathrm{CH}_{4}$ similar but subordinate to $\mathrm{H}_{2} \mathrm{O}$. The quartz normative composition obtained by melting with $20 \%$ added volatile is consistent with a large expansion of the olivine phase field as might be expected from the addition of a large ammount of depolymerizing mixed volatile.

The results presented here are preliminary but clearly demonstrate that under constant temperature, pressure and $\mathrm{fO}_{2}$ the liquids generated by partial melting of peridotite can vary from substantially nepheline normative through hypersthene to quartz normative compositions. It follows that in addition to temperature, pressure and $\mathrm{fO}_{2}$ it is important 
to consider the amount of volatile present in determining the genesis of any magma for which there is evidence for a role for volatiles.

\section{References:}

Falloon, T.J., Green,D.H., Hatton, C.J. and Harris, K.L. (1988) Anhydrous partial melting of Fertile and Depleted peridotite from 2 to $30 \mathrm{kbar}$ and application to basalt petropgenesis. Journal of Petrology, 29, 1257-1282.

Green, D.H.(1976) Experimental testing of equilibrium partial melting of peridotite under water saturated, high pressure conditions. Canadian Mineralogist, 14, 255-268.

Roeder, P.L. and Emslie,R.F.(1970) Olivine-liquid equilibrium. Contributions to Mineralogy and Petrology, 29, 275-289.

Stolper,E.(1980) A phase diagram for Mid Ocean Ridge Basalts: preliminary results and implications for petrogenesis. Contributions to Mineralogy and Petrology 74, 7-12.

Taylor,W.R. and Green,D.H.(1987) The petrogenetic Role of Methane and the effect on liquidus phase and the solubility mechanism of reduced $\mathrm{C}-\mathrm{H}$ volatiles. In. B.O.Mysen, Ed. The Geochemical Society Special Publication 1, 139-154.

Table 1. Calculated partial melt compositions.

$\begin{array}{lrrrrrrrrrrr} & \mathrm{SiO}_{2} & \mathrm{TiO}_{2} & \mathrm{Al}_{2} \mathrm{O}_{3} & \mathrm{Cr}_{2} \mathrm{O}_{3} & \mathrm{FeO} & \mathrm{MgO} & \mathrm{CaO} & \mathrm{Na}_{2} \mathrm{O} & \mathrm{K}_{2} \mathrm{O} & \mathrm{MnO} & \text { Total } \\ \text { ED63 } & 46.45 & 5.92 & 17.93 & 0.10 & 6.00 & 9.06 & 8.11 & 4.06 & 1.94 & 0.19 & 99.76 \\ \text { ED58 } & 47.53 & 3.16 & 12.76 & 0.14 & 8.48 & 14.32 & 10.72 & 1.95 & 0.67 & 0.04 & 99.77 \\ \text { ED65 } & 50.98 & 1.77 & 13.35 & 0.36 & 7.46 & 12.60 & 12.38 & 0.50 & 0.34 & 0.18 & 99.92\end{array}$

Figure 1.

CIPW Normative projection from diopside onto the plane Jd+CaTs-Qz-Ol. Dashed lines indicate the position of Olivinetorthopyroxenetclinpyroxene cotectics for 2-25 kbar(after Falloon et al.,1988).

Open symbols: melt inclusion analyses.

closed symbols: Calculated average liquid compositions of Table 1 .

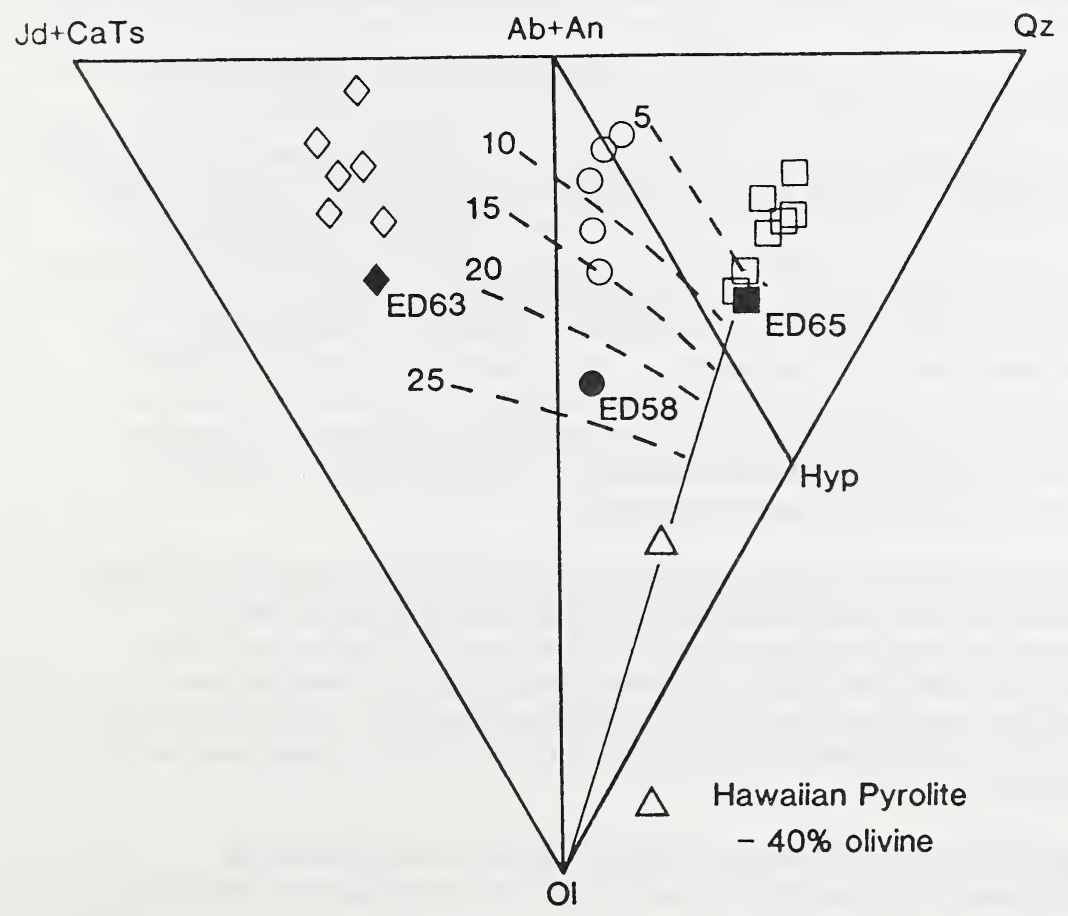

